University of Nebraska - Lincoln

DigitalCommons@University of Nebraska - Lincoln

Management Department Faculty Publications

Management Department

2010

\title{
Commanding board of director attention: Investigating how organizational performance and CEO duality affect board members' attention to monitoring
}

Chris S. Tuggle

University of Nebraska-Lincoln, ctuggle2@unl.edu

David G. Sirmon

University of Washington - Seattle Campus, dsirmon@uw.edu

Chris R. Reutzel

Utah State University, christopher.reutzel@usu.edu

Leonard Bierman

Texas A \& M University - College Station, lbierman@mays.tamu.edu

Follow this and additional works at: http://digitalcommons.unl.edu/managementfacpub

Part of the Strategic Management Policy Commons

Tuggle, Chris S.; Sirmon, David G.; Reutzel, Chris R.; and Bierman, Leonard, "Commanding board of director attention: Investigating how organizational performance and CEO duality affect board members' attention to monitoring" (2010). Management Department Faculty Publications. 117.

http://digitalcommons.unl.edu/managementfacpub/117

This Article is brought to you for free and open access by the Management Department at DigitalCommons@University of Nebraska - Lincoln. It has been accepted for inclusion in Management Department Faculty Publications by an authorized administrator of DigitalCommons@University of Nebraska - Lincoln. 


\title{
Commanding board of director attention: Investigating how organizational performance and CEO duality affect board members' attention to monitoring
}

\author{
Christopher S. Tuggle, ${ }^{1 *}$ David G. Sirmon, ${ }^{2}$ Christopher R. Reutzel, ${ }^{3}$ and Leonard Bierman ${ }^{2}$
}

1. Trulaske College of Business, Management Department, University of Missouri, Columbia, Missouri

2. Mays Business School, Management Department, Texas A\&M University, College Station, Texas 3. Jon M. Huntsman School of Business, Utah State University, Logan, Utah

Corresponding author - Christopher S. Tuggle, current email ctuggle2@unl.edu

\begin{abstract}
Boards of directors' attention to monitoring represents an understudied topic in corporate governance. By analyzing hundreds of board meeting transcripts, we find that board members do not maintain constant levels of attention toward monitoring, but instead selectively allocate attention to their monitoring function. Drawing from the attention-based view, prospect theory, and the literature on power, we find that deviation from prior performance and CEO duality affect this allocation. Specifically, while negative deviation from prior performance increases boards' attention to monitoring, positive deviation from prior performance reduces it. The presence of duality also reduces the boards' allocation of attention to monitoring. Additional analysis demonstrates that the effects of duality are realized in part by the CEO-chair's control of the meeting's agenda and location. Finally, the results show that duality and deviation from prior performance interactively affect boards' attention to monitoring. In total, we find that board members do not consistently monitor management in order to protect shareholder value, a proposition often assumed within governance research; rather, our results demonstrate that board members' monitoring behaviors are contextually dependent. The contextual dependency of board attention to monitoring suggests that additional efforts may be needed to ensure the protection of shareholders' interests.
\end{abstract}

Keywords: board of directors, monitoring, CEO duality, attention-based view, prospect theory, power

\section{Introduction}

The role of boards of directors in corporate governance represents a broadly studied topic (Daily, Dalton, and Cannella, 2003a; Finkelstein, Hambrick, and Cannella, 2009). The primary theoretical lens used to investigate boards of directors has been agency theory (Dalton et al., 2007). Agency theory argues that by monitoring, corporate board members can observe and control senior managers' interests such that they do not diverge substantially from those of owners (Dalton et al., 2007), thereby mitigating, at least partially, various costs associated with the separation of ownership and control (Fama, 1980; Fama and Jensen, 1983b). For this reason, monitoring management, especially 
top executives, represents a highly important task for board members.

Because of its importance, the monitoring role of boards has been the focus of extensive corporate governance research (e.g., Hermalin, 2005; Johnson, Daily, and Ellstrand, 1996; Monks and Minow, 2004). Within this stream of work, the influence of a board's composition (e.g., independence of board members) and structure (e.g., duality) on its monitoring role has been of great interest (Dalton et al., 2007; Finkelstein and Hambrick, 1996; Johnson et al., 1996). In fact, many empirical studies utilize board composition and structure variables as proxies for board monitoring (Kroll, Walters, and Wright, 2008). However, we argue there is more to understanding the monitoring function of boards than merely observing their composition and structure.

We assert that, like all social actors, board members face significant limitations in their information processing and calculation capabilities (Cyert and March, 1992; Simon, 1947). These limitations force board members to selectively attend to certain issues and thereby forgo others (Ocasio, 1997). In other words, board members' attention, "the noticing, encoding, interpreting, and focusing of time and effort" on a particular issue or issues (Ocasio, 1997: 189), is limited. Therefore, even though monitoring management is a highly important task, we expect the allocation of attention to monitoring - that is, "the noticing, encoding, interpreting, and focusing of time and effort" on the act of monitoring - to vary (Hillman, Nicholson, and Shropshire, 2008). But, because "much of agency theory is closer in spirit to an unbounded rationality tradition than to limited rationality" (Cyert and March, 1992: 222; Williamson, 1988), most prior board studies assume that directors allocate attention to monitoring consistently. However, this assumption lacks both theoretical and empirical support, which might explain the inconclusive results of studies that have attempted to link monitoring with firm-level outcomes (Dalton et al., 1998, 2007). We take a different approach, endeavoring to identify what factors affect boards' allocation of attention to monitoring and how these factors increase or decrease that allocation.

To theoretically ground our investigation of board members' allocation of attention to monitoring, we draw upon the attention-based view (ABV) (Ocasio, 1997). At its core, the ABV argues "that what decision makers do depends on where they focus their atten- tion" (Barnett, 2008: 606). Moreover, the ABV argues that decision makers' allocation of attention is in turn influenced by 1) contextual factors and 2) the structure of the decision makers' interaction. Accordingly, the $\mathrm{ABV}$ suggests that board members' attention to monitoring represents an important antecedent to actual monitoring, yet the allocation of attention to monitoring is expected to vary based on contextual and structural factors. Because the theoretical mechanisms within the ABV have been "expressed at a relatively general level" (Cho and Hambrick, 2006: 453), related empirical research often focuses on factors of specific importance to the identified decision makers: for example, top management teams (e.g., Bouquet and Birkinshaw, 2008; Cho and Hambrick, 2006; Kaplan, 2008; Yadav, Prabhu, and Chandy, 2007; Yu, Engleman, and Van de Ven, 2005). With respect to directors' allocation of attention to monitoring, $\mathrm{ABV}$ logic helps identify firm performance and duality as especially relevant factors. First, as a contextual factor, firm performance is relevant given its use by directors as a means to assess managerial effectiveness (Walsh and Seward, 1990). More specifically, we suggest that deviation from prior performance helps quantify managerial effectiveness and thus influences board members' allocation of attention to monitoring. Second, CEO duality represents a fundamental element in the structural arrangement of a board that can affect board members' interaction (Finkelstein and D'Aveni, 1994; Finkelstein et al., 2009). Thus, duality is also expected to influence board members' allocation of attention to monitoring.

Next, to improve our understanding of how these factors increase or decrease the allocation of attention to monitoring, we draw upon prospect theory (Kahneman and Tversky, 1979; Tversky and Kahneman, 1981, 1992) and the literature on power (Lukes, 1974; Pfeffer, 1981, 1992). These perspectives complement our use of $\mathrm{ABV}$ by identifying how deviation from prior performance and duality, both directly and interactively, affect boards' allocation of attention to monitoring.

This study makes multiple theoretically and empirically important contributions to the literature. First, we bring a novel theoretical perspective to research on corporate governance by extending the $\mathrm{ABV}$ to the realm of corporate boards. In contrast to prior research, which relies on an assumption of rationality and coarse-grained proxies of monitoring 
(Baliga, Moyer, and Rao, 1996; Boyd, 1995; Brickley, Coles, and Jarrell, 1997), we instead address and measure boards' allocation of attention to monitoring with much more fine-grained proxies and with an assumption of bounded rationality. To test our model, we analyze hundreds of detailed transcripts of actual board meetings. This provides a missing large-sample, yet fine-grained, view of internal board meeting processes, allowing us to enhance our theoretical understanding of board monitoring by responding to Pettigrew's (1992) call to move beyond what boards look like and study what boards actually do. Indeed, our results show that instead of maintaining a constant allocation of attention to monitoring, board members vary their allocation of attention to monitoring based on deviations from prior firm performance and the presence or absence of CEO duality. Thus, investigating boards' allocation of attention to monitoring offers a new avenue to understand the extent to which boards address their monitoring function.

Second, by incorporating insights from prospect theory, we turn around what has been a frustrating search for a monitoring-performance link (Dalton et al., 2007) and find support for our theoretical discussion of how performance influences a board's attention to monitoring. Third and relatedly, by showing, theoretically and empirically, how duality affects a board's allocation of attention to monitoring (as opposed to its being a proxy of monitoring), we increase our understanding of how duality matters. Instead of treating CEO duality as a proximal antecedent of firm performance, as is often the case, we find that it provides power to influence the board's allocation of attention to monitoring. Our work thus suggests that if duality has any influence on performance, it will likely be indirect (Daily et al., 2003a).

This paper begins by noting agency theory's contributions and limitations in addressing the board monitoring function.We then provide a more elaborate discussion of the important factors that affect board members' allocation of attention to monitoring based on ABV logic. Next we draw upon prospect theory and the literature on power to develop our hypotheses. Following this, we present the details of our methodological approach, with particular emphasis on the empirical treatment of the board meeting transcripts. Finally, we close with a discussion of the results and implications for theory and practice.

\section{Theoretical framework and hypotheses}

Agency theory represents the primary theoretical framework employed to examine the monitoring role of corporate boards (Dalton et al., 2007). Agency theory posits that as a result of the separation between ownership and control, managers' interests potentially conflict with those of stockholders (Fama, 1980; Fama and Jensen, 1983b). Specifically, agency theory suggests that top managers may choose to pursue strategies and activities that benefit themselves at the expense of stockholders (Eisenhardt, 1989; Jensen and Meckling, 1976). Accordingly, agency theorists view the monitoring of managements' actions as a primary role of boards of directors, one that protects shareholders' interests (Dalton et al., 2007; Hillman and Dalziel, 2003).

However, empirical research from an agency perspective is equivocal with respect to the issue of board monitoring. For example, Wright, Kroll, and Elenkov (2002) conclude that board monitoring is affected by outside directors. Specifically, they found post-acquisition CEO compensation changes were based on performance criteria when the board was composed of more outside directors, while post-acquisition CEO compensation changes were based on size (changes in total assets) when the board was composed of fewer outside directors. Likewise, other research has found equity ownership of outside directors to be linked to greater levels of monitoring (Hambrick and Jackson, 2000). However, neither Dalton et al.'s (1998) meta-analysis nor Dalton et al.'s (2007) literature review revealed support for this relationship or agency prescriptions in general. Thus, while some have concluded, and policy has followed the assumption, ${ }^{1}$ that 'more independent outside directors, blockholder board membership, and board member ownership indicate that directors are vigilant as monitors' (Kroll et al., 2008: 364), more work appears to be needed to understand what factors influence board monitoring and how those factors operate.

1. This belief is evidenced in the passage of regulations in many countries (e.g., Sarbanes-Oxley Act, New York Stock Exchange, and NASDAQ requirements in the United States; Cadbury and Hampel report requirements in the United Kingdom; and the Toronto Stock Exchange requirements in Canada) that mandate outside directors on boards. See Dahya and McConnell (2005) for an outline of 18 different countries that have instituted such corporate governance regimes. 
Certainly, monitoring requires monitors to engage in such behavior. However, agency theory "gives a much smaller weight to limited rationality, as opposed to conflict" (Cyert and March, 1992: 221). Thus, agency-based prescriptions such as increased outside directors, blockholders, and board member ownership assume, at least implicitly, that board members are capable of attending fully to all matters, including monitoring. From an ABV, however, such assumptions are inaccurate (Ocasio, 1997; Simon, 1947). In fact, outside of agency theory, several streams of research concerned with governance, such as those taking a social psychological and strategic leadership perspective, do not assume board member rationality (e.g., Finkelstein et al., 2009; Westphal, 1998; Westphal and Fredrickson, 2001). For example, a series of studies by Westphal and colleagues demonstrate how social processes such as ingratiatory behavior, social distancing, and director experiences influence board monitoring behaviors (e.g., Westphal, 1998; Westphal and Fredrickson, 2001; Westphal and Khanna, 2003; Westphal and Zajac, 1997). These studies underscore the importance of how context affects the selective focus of director attention.

Building on Simon's (1947) ideas, Ocasio (1997) puts forth three principles supporting the ABV. The first is focused attention, or the notion that decision makers attend to issues based on the focus of their attention. The second is situated attention, or the idea that the focus of an actor's attention is affected by contextual factors. The third is structural distribution of attention, or the idea that controls (e.g., rules, formal committee structure, agenda for meetings, etc.), used inclusively, affect the focus of an actor's attention. Thus, paramount to the ABV is the notion that actors selectively allocate attention (which facilitates perception and deliberation) toward some objects or ideas, and away from others. Selective allocation of attention is necessary because decision makers cannot effectively attend to all possible stimuli, but instead must choose among competing targets. Moreover, selective allocation of attention is important because it influences the actions in which decision makers eventually engage. Therefore, understanding the contextual and structural factors that influence an actor's selective allocation of attention can help in understanding the actor's behavior.

A variety of issues may compete for board member attention. Perhaps most importantly to corporate functioning, board members must choose how much attention to allocate to their multiple board responsibilities. Within their roles as directors, they often must allocate their attention to various functions such as resource provision, environmental scanning, opportunity seeking, and monitoring (Hillman and Dalziel, 2003; Johnson et al., 1996; Zahra and Pearce, 1989). However, because monitoring top management may represent the most fundamental function of board members (Fama and Jensen, 1983b; Jensen and Meckling, 1976; Zald, 1969), we limit our investigation to understanding factors that influence the allocation of board attention to monitoring (Dalton et al., 2007; Finkelstein et al., 2009). This focus may be particularly valuable because the ABV suggests that monitoring first requires that boards allocate attention to this important function. ${ }^{2}$

Identifying factors salient to board members' allocation of attention to monitoring can be facilitated by considering the principles of situated attention and structural distribution of attention, both developed by Ocasio (1997). First, using the principle of situated attention, we identified firm performance as a contextual factor highly important to board members. More specifically, deviation from prior performance gives the board a contextual factor to assess management against shareholder concerns and is thus expected to be especially relevant to board members' allocation of attention to monitoring (Fama and Jensen, 1983b; Zald, 1969). Second, based on the principle of structural distribution of attention, Ocasio (1997: 195) argues that any factor that influences "the agenda for the meeting" or "the formal structure of the committee" is likely to be very important. Thus, the formal structure of the board is expected to affect the allocation of attention. Specifically, the presence of CEO duality, as an element of the board"s formal structure, is especially relevant to board members' allocation of attention to monitoring. In sum, applying $\mathrm{ABV}$ logic to boards of directors suggests that to make better sense of board monitoring, the context

2. While increased allocations of attention to monitoring are likely to increase the actual behavior of monitoring, they do not guarantee any level of quality. Therefore, we argue that attention is essential but not necessarily sufficient for monitoring effectiveness. 
and structure of the board need to be considered, and that deviation from prior performance and duality are especially important factors in determining the allocation of attention to monitoring.

Next we develop the theoretical logic of our hypotheses. Building on the insights that the ABV offers, we first draw upon prospect theory to explain how deviation from prior performance affects directors' allocation of attention to monitoring. Then we draw on the power literature to facilitate our investigation of how duality affects the allocation of attention to monitoring. Finally, we investigate the interactive relationship between deviation from prior performance and duality.

\section{Performance and attention to monitoring}

Breaking away from assumptions of rational, utility maximizing decision making, Kahneman and Tversky's prospect theory (i.e., Kahneman and Tversky, 1979; Tversky and Kahneman, 1981, 1992) describes how problem framing affects behavior. Prospect theory suggests that preferences for risky behavior change depending on how alternatives compare to a point of reference (Shimizu, 2007). This perspective is similar to that proposed by behavioral decision theory (Greve, 2003; Wiseman and GomezMejia, 1998). In fact, prior work has noted the marked similarity between the two theories (Audia and Greve, 2006; Shimizu, 2007). Summarizing insights from these theories, Audia and Greve (2006) state that decision makers 1) focus on deviation from a reference level of performance, 2) code this deviation as failure when current performance is below the reference and success when above, and 3) are more motivated to overcome failure than to continue success. While prospect theory is used primarily to address actors' risk preferences, Greve (2003: 696) suggests that growing empirical results show that "performance relative to aspiration level functions as a "master switch" that affects a wide range of organizational behaviors." For example, performance deviation has been shown to affect outcomes ranging from CEO advice-seeking behavior (McDonald and Westphal, 2003) to resource management actions (Morrow et al., 2007; Sirmon, Gove, and Hitt, 2008; Sirmon, Hitt, and Ireland, 2007; Sirmon, Hitt, Arregle, and Campbell, in press). We suggest that, as a "master switch," devia- tion from prior performance will affect the boards' allocation of attention to monitoring top managers.

Deviation from prior performance may be especially salient to the board for at least two reasons. As discussed previously, the board has a fiduciary responsibility to shareholders to monitor and assess the performance of management (Zald, 1969). Boards often use firm performance as a proxy for management effectiveness because of the complexity and ambiguity surrounding the managerial task (Walsh and Seward, 1990). Moreover, firm performance is a very high priority for most shareholders.

Second, firm performance has reputational consequences for board members (Fama, 1980). While the reputations of members serving on the boards of high-performing firms may be enhanced, the converse is also true. In fact, negative reputational costs may be a greater concern for board members. Research shows that significant negative reputation costs accrue to board members of poorly performing firms, especially if financial restatement is necessary (Srinivasan and Richardson, 2005). Consequently, board members' motivation to monitor management is based partially on self-interested protection of their reputations and potential future earnings (Fama and Jensen, 1983a).

We posit that together, director fiduciary responsibility and reputational effects will affect the attention boards allocate to monitoring management. Prospect theory suggests that the "win" framing that positive deviation from prior performance constitutes will lead boards to conclude that management is acting in the best interest of shareholders and directors, and that positive deviation is therefore likely to prompt board members to allocate less attention to monitoring management. For example, the Rockefeller family, which still owns as much as one percent of the ExxonMobil Corporation (Krauss, 2008; Mufson, 2008), recently charged that the firm"s unusually strong current performance has led that company's board to become "myopic" and engage in relatively little monitoring of company management (Clark, 2008). Conversely, prospect theory suggests that "loss" framing of negative deviation from prior performance will lead boards to allocate more attention toward monitoring management to prevent financial losses for shareholders and reputational costs for themselves. Therefore, we hypothesize the following: 
Hypothesis 1a: Negative deviation from prior performance will increase the board's allocation of attention to monitoring.

Hypothesis 1b: Positive deviation from prior performance will decrease the board's allocation of attention to monitoring.

By drawing upon the $\mathrm{ABV}$ to highlight board members' limited information processing capabilities, we have suggested that boards do not allocate equal amounts of attention to every issue (Cho and Hambrick, 2006; Cyert and March, 1992); rather, they allocate attention based on the importance of the issue they face (Ocasio, 1997). Prospect theory suggests that decision makers are often more motivated to take assertive behavior to prevent loss than to achieve additional gains. Combining these insights, we suggest that changes in the allocation of attention to monitoring will differ across the range of performance deviation. Specifically, we suggest that the effects of prior performance deviation on boards' allocation of attention to monitoring, instead of being equal, will be greater in the context of negative rather than positive deviation from prior performance.

Hypothesis 2: The effect of negative deviation from prior performance on the board's allocation of attention to monitoring is greater than the effect of positive deviation.

\section{Duality and attention to monitoring}

Other considerations besides contextual factors affect board members' allocation of attention. Structural factors, such as CEO duality, also play an important role. Combining arguments derived from the power literature with $\mathrm{ABV}$, we suggest that $\mathrm{CEO}$ duality is relevant because it may allow the CEO to limit board members' allocation of attention to monitoring.

CEO duality refers to instances in which the same person holds the titles of CEO and chairperson of the board of directors in a corporation (Baliga et al., 1996; Rechner and Dalton, 1989). CEO duality is often viewed as an impediment to the board's monitoring of top executives (Baliga et al., 1996; Finkelstein and D'Aveni, 1994) and can serve to entrench a CEO within an organization by compromising a board's ability to monitor and discipline management (Mallette and Fowler, 1992).

Corporate CEOs, with or without duality, generally have incentives to direct board attention away from monitoring. As Walsh and Seward succinctly note:

Top managers are well aware of their precarious employment situations. Consistent with the evidence in the turnover literature, they know that they are at risk of being dismissed for suboptimal organizational performance, even if they did not contribute to the problem. Valuing their position, many executives work to ensure their own job security. Toward that end, they have no choice but to tamper with the board's ability to monitor and control their performance (Walsh and Seward, 1990: 430-431).

In view of the extra power that duality affords a CEO (Cannella and Lubatkin, 1993), it is reasonable to expect CEO-chairs to divert the board from monitoring top management.

Prior research shows that duality affects CEO compensation (Conyon and Peck, 1998), earnings management (Davidson et al., 2004), CEO succession (Cannella and Lubatkin, 1993; Goyal and Park, 2002), and stock market performance (Coles, McWilliams, and Sen, 2001; Dalton et al., 1998). Moreover, prior research suggests that CEO duality empowers the CEO and weakens the board of directors (e.g., Cannella and Lubatkin, 1993; Finkelstein and D'Aveni, 1994). Particularly salient to this study is the notion that CEO duality affords CEOs the wherewithal to entrench themselves within their respective firms. Specifically, the power associated with CEO-chairs may enable them to create norms in which it is inappropriate to question management's effectiveness (Mace, 1971). Such circumstances likely reduce the board's proclivity to monitor management, resulting in less board attention to monitoring. For instance, in 2008, Rockefeller family members charged that the current CEO duality structure at ExxonMobil has hampered the ability of the company's board to ask "tough questions" (Krauss, 2008: C6). In sum, we argue that duality will negatively affect the board's allocation of attention to monitoring. Formally: 
Hypothesis 3: CEO duality will negatively affect the board's allocation of attention to monitoring.

\section{Duality, performance, and attention to monitoring}

Hillman and colleagues $(2003 ; 2008)$ note that monitoring top management requires both ability and motivation on the part of board members. However, as argued above, duality may enable the CEO to affect the board's ability to monitor, while performance deviation affects the board's motivation to monitor. Thus, the effects of deviation from prior performance on the board's allocation of attention to monitoring are expected to change in the presence of duality.

Poor firm performance is often a key contextual factor boards of directors consider in cases of CEO dismissal. However, research on CEO dismissal suggests that duality weakens the relationship between poor firm performance and the likelihood of CEO dismissal (Fredrickson, Hambrick, and Baumrin, 1988). Thus, duality tilts the balance of power in favor of the CEO such that even as firm performance deteriorates, board monitoring can be impeded. As Finkelstein and Hambrick note, "when the balance of power favors boards, they will be more vigilant in monitoring and disciplining top management; when CEOs are more powerful, boards will be ineffective monitors" (Finkelstein and Hambrick, 1996: 223). As the deviation from prior performance becomes increasingly negative, CEO-chairs may be more inclined to exercise their influence over their board's monitoring efforts in order to protect their jobs (Walsh and Seward, 1990).

On the other hand, in the context of positive deviation from prior performance, where board attention to monitoring is already decreasing, the power that duality affords the CEO is expected to amplify this relationship. For example, in May 2008, ExxonMobil CEO and Chairman Rex Tillerson, in the context of the company's unusually strong recent performance, orchestrated a clear defeat of a campaign by the Rockefeller family to eliminate CEO duality at the company (Gold and Eaton, 2008; Mufson, 2008). In sum, we hypothesize the following:

Hypothesis 4a: CEO duality moderates the relationship between negative deviation from prior performance and the board's allocation of atten- tion to monitoring such that duality weakens the relationship.

Hypothesis $4 \mathrm{~b}$ : CEO duality moderates the relationship between positive deviation from prior performance and the board's allocation of attention to monitoring such that duality amplifies the relationship.

\section{Methods}

\section{Sample}

Our initial sampling frame for this study consists of the publicly traded firms in 18 industries. Publicly traded firms were used because Securities and Exchange Commission (SEC) reporting makes information on board of director characteristics publicly available and because the required board meeting transcripts are commonly of higher quality for firms accountable to the SEC. However, these board meeting transcripts are not publicly available. Thus, we needed to obtain firms' participation in order to analyze their board transcripts. (For details regarding how the sample for this study was obtained, see Appendix A.)

In total, 178 publicly traded firms' board transcripts were analyzed for this study. We analyzed these transcripts for the years 1994 through 2000. However, events such as mergers, delisting, failure to file with SEC, and bankruptcy resulted in some of the firms not having complete data over this time period. Thus, an unbalanced panel dataset consisting of 979 firm-year observations represents our final sample.

We tested for sample-inclusion bias by comparing the characteristics of the firms that "opted into" this study and firms that did not, using the KolmogorovSmirnov two-sample test. This tests whether two distributions differ and whether it is reasonable to assume the samples come from the same population. Across all the archival variables in the study, the results showed no statistically significant difference between the "opted-in" and "opted-out" firms.

\section{Dependent variable}

To measure the amount of attention boards pay to their monitoring role, we used a form of content, or text, analysis. Content analysis is based on the 
assumption, consistent with the Sapir-Whorf hypothesis, that word choice reflects the "cognitive categories" individuals use to allocate their attention (Cho and Hambrick, 2006; Sapir, 1944; Whorf, 1956). "Words that are frequently used are cognitively central and reflect what is most on the user's mind; words that are used infrequently or not at all are at the cognitive peripheral, perhaps even representing uncomfortable or alien concepts" (Cho and Hambrick, 2006: 459; Huff, 1990; Tuggle, Schnatterly, and Johnson, 2010). Researchers have used such analysis in numerous organizational studies, often examining publicly available firm documents such as letters to shareholders or annual reports (e.g., Abrahamson and Park, 1994; Bowman, 1984; Clapham and Schwenk, 1991). Prior empirical studies have supported the usefulness of analyzing organizational communications (e.g., letters to shareholders) to investigate phenomena such as competitive aggressiveness (Chen and Hambrick, 1995; Chen and Macmillan, 1992; Chen and Miller, 1994), total number of actions (Young, Smith, and Grimm, 1996), and strategic change (Cho and Hambrick, 2006).

Because letters to shareholders, as well as many other forms of public communications, are carefully scripted documents, attempts to analyze their meaning should proceed cautiously (Yadav et al., 2007). Nevertheless, prior studies have found the content of these letters are related to firm actions (Barr, 1998; D'Aveni and Macmillan, 1990; Yadav et al., 2007). In contrast to the scripted nature of letters to shareholders, board meeting transcripts are not carefully constructed or selectively edited by management. Rather, they simply account for board meeting discussions.

To explore the boards' allocation of attention to their monitoring role, we developed a list of words and phrases consistent with behaviors related to the monitoring function. We relied on the management, finance, and legal literatures encompassing concepts such as monitoring, control, ${ }^{3}$ agency of directors, and corporate governance to guide the development of the initial "indicator" word/phrase list. ${ }^{4}$ Next, thesauruses helped identify major synonyms of these indicator words. Employing an iterative process during pilot coding of nonsample minutes, we added and deleted words until the impact of any further addition or deletion was considered to be minimal. The final word and phrase list contains words and phrases, focus questions, and guiding definitions of monitoring-related behaviors.

The actual coding process was designed as a threestage procedure built on prior studies that have utilized words (e.g., Cho and Hambrick, 2006) or sentences (e.g., D'Aveni and Macmillan, 1990; Yadav et al., 2007) as the focal unit of analysis. After the indicator word and phrase list was finalized, and the concluding coding pretest was conducted, coders began coding the sample transcripts. For their first task, coders identified the indicator words and phrases within the board discussion text. Next, they identified the applicability or supporting nature (to our study) of the sentences surrounding these words and phrases. Finally, coders measured the duration in minutes that each board spent discussing monitoring topics related to its firm.

As noted above, before coders examined the sample firm's board transcripts, they trained with nonsample firm transcripts. Initial interrater reliability scores were 0.78 (Krippendorff's alpha). ${ }^{5}$ After additional discussions and further training, coders investigated a second pretest transcript on which interrater reliability improved to 0.89 .6

Following the logic in several content analysis studies that suggests greater discussion implies greater attention (Sonpar and Golden-Biddle, 2008), we operationalize board of director allocation of attention to monitoring as the time spent discussing monitoring-related issues over the total meeting time for all meetings in a year. Also, both the numerator and denominator were coded as minutes spent. We use percentage of yearly meeting time as our unit of analysis based on the premise that discussion of mon-

3.Words related to "control" were coded as well because it is often referred to as a substitute for (Zajac and Westphal, 1994) and/or a complement to (Milgrom and Roberts, 1992) monitoring.

4. The complete list of words is available from the authors. Examples of monitoring and control "indicator" words and phrases include "executive compensation," "firm performance (evaluation)," and "hiring of top management."

5. Like Cohen's kappa, Krippendorff's alpha is a reliability coefficient developed to measure intercoder agreement. However, Krippendorff's alpha accommodates multiple coders (more than two) and interval/ratio-level data. See Krippendorff (2004) for further explanation of this measure.

6. Upon completion of the coding by the second or, when applicable, the third coder, all the coders for a specific set of transcripts met to resolve the coding differences. After completing this discussion of coding discrepancies, there was a 98.3 percent rate of agreement among coders. 
itoring (when considered as a percentage of a whole) excludes or minimizes discussion of other topics. (For more detailed explanation of the protocols we designed to increase the reliability of our dependent variable, please refer to Appendix B.)

\section{Independent variables}

Duality is defined as a CEO's also being the chairperson of the board. Following prior research, a dummy variable was used to code duality (duality=1). These data, along with several control variables discussed below (i.e., director tenure, director age, outsider ownership, outside director percentage, board size, insider ownership, and institutional ownership) were collected through publicly available corporate filings.

Deviation from prior performance is hypothesized to affect board member behavior. We followed prospect theory in constructing this variable. Prospect theory argues performance relative to an aspiration level affects behavior. Specifically, Audia et al. (2006) suggest aspiration levels typically represent recent performance. Thus, deviation from prior performance is current performance compared with the average of the prior two years' performance. We measured firm performance with both return on equity (ROE) and return on assets (ROA), but these variables were analyzed in separate models. These data were collected from COMPUSTAT.

\section{Control variables}

We use nine control variables in the analysis. The literature on group size suggests that larger groups are difficult to manage (Gladstein, 1984) and complicate information processing (Haleblian and Finkelstein, 1993). The effect of board size on board participation in prior research is mixed. Some scholars suggest that board participation is negatively associated with board size on topical depth but positively associated with board size on topical breadth (Finkelstein and Hambrick, 1996). Judge and Zeithaml (1992) find that the size of a board and board involvement are negatively related. Zahra, Neubaum, and Huse (2000) found a curvilinear relationship between board size and corporate entrepreneurship that was initially positive but became negative when the number of directors reached 11 in their sample of me- dium-size companies. Accordingly, we control for board size with the firm's number of directors.

Next, we control for a board's relative power using two variables: 1) board relative tenure and 2) outside director equity ownership. Relative board tenure was operationalized as the average of directors' board tenure divided by CEO tenure. Outside director ownership percentage was operationalized as the number of shares owned by outsiders divided by the total number of outstanding shares.

Additionally, we control for board independence, defined in terms of firm insiders and outsiders. We classified board members as insiders if they were employed by the firm or had very strong ties to the firm or its executive officers. Specifically, we coded directors as "insider," "affiliated - family or former employee," "affiliated - professional relationship with firm," or "outsider." Thus, we operationalized board independence by calculating each board's outside director percentage. Also, because a board member's age might be an indicator of his or her likely openness to new ideas about board independence and directors' monitoring role, we control for average director age in all models (Zajac and Westphal, 1996).

We also control for insider ownership percentage because a high level of insider equity holdings suggests a natural alignment of shareholder and management interests and consequently less need for monitoring. Insider ownership percentage was operationalized as the number of shares owned by insiders divided by the total number of outstanding shares.

Also, prior research has found that institutional investors apply considerable pressure to boards to monitor top managers (Hoskisson et al., 2002; Westphal and Zajac, 1998). Therefore, we control for institutional ownership percentage with the total number of shares held by pension funds, banks and trust companies, savings and loans, mutual fund managers, and labor union funds divided by total common stock. Next, because evidence suggests firm size may affect board decision making (Finkelstein and Hambrick, 1996), we control for firm size with the natural $\log$ of annual gross sales. These data were obtained from COMPUSTAT.

Lastly, we control for another reference point the board may utilize in evaluating management: industry performance. Specifically, we control for the firm's deviation from industry performance by using the average firm performance within its primary indus- 
try, based on three-digit Standard Industrial Classification (SIC) codes. This is important because performance relative to industry affects how boards evaluate CEOs as well as CEO turnover (Gibbons and Murphy, 1990; Morck, Shleifer, and Vishny, 1989). We operationalized deviation from industry performance as the difference between the industry's average performance and the firm's performance, divided by the industry average performance. This procedure was conducted for both ROE and ROA.

\section{Analytical approach}

We employed a fixed-effects panel methodology to analyze the data. A Hausman test yielded a statistically significant result, which suggests that the use of fixed effects was more appropriate than a random-effects specification for these data. Additionally, a fixed-effects application minimizes problems with autocorrelation and heteroskedasticity (Bowen and Wiersema, 1999; Hitt, Gimeno, and Hoskisson, 1998; Sayrs, 1989), while controlling for unobserved firm- and year-specific heterogeneity (Greene, 2002). Accordingly, the timeinvariant effects, such as industry membership, are addressed via the fixed-effects procedure.

Additionally, to accurately test our hypotheses, we utilize spline functions in our models. Spline functions are useful in testing theories that suggest a continuous relationship will change slopes at critical thresholds (Greene, 2002; Marsh and Cormier, 2002). Spline functions help depict differences in a construct of interest above and below the threshold level (Greve, 1998, 2003; Sirmon and Hitt, 2009). In our study, we examine outcomes when performance deviates above and below the average of the past two years' performance. Instead of splitting the sample and modeling various subsamples individually, which would disrupt the continuity of the function, spline functions allow continuous relationships to meet and change slopes at theoretically determined threshold points, called "knots" (Greene, 2002; Marsh and Cormier, 2002). In our study, the knot is theoretically determined to be the status quo ( $\mathrm{Au}-$ dia and Greve, 2006). More specifically, a spline function splits a single continuous variable into two separate variables, allowing one to model the relationship "above the knot," while the other models the relationship "below the knot." In this study, deviations from prior performance are separated into negative deviation and positive deviation. Importantly, we created a lag structure in our dataset. Specifically, all independent and control variables were measured in period $t$, while the dependent variable was lagged one year.

\section{Results}

Table 1 provides descriptive statistics and bivariate correlations among the variables. All variables used to construct interaction terms were centered prior to calculating interaction terms. To test for the presence of multicolinearity, we followed procedures outlined by Neter, Wasserman, and Kutner (1985). The largest variance inflation factor was 2.42, well below the commonly accepted threshold of 10, which indicates multicolinearity is not an issue.

Table 2 presents the results of our analyses. Models $1 \mathrm{a}$ and $1 \mathrm{~b}$ in Table 2 include only the control variables. As seen in both Model 1a and 1b, average director age and insider ownership percentage are negatively and significantly related to boards' attention to monitoring. Thus, increased age and insider ownership reduce a board's attention to the monitoring of management. Additionally, institutional ownership and outside directors have positive and significant coefficients. This suggests that higher institutional ownership percentage increases boards' attention to monitoring. Likewise, independence increases boards' attention to monitoring management. The other control variables show no statistically significant effect on a board's attention to monitoring.

Models $2 \mathrm{a}-4 \mathrm{~b}$ progressively display the results of the hypotheses tests. Hypotheses $1 \mathrm{a}$ and $1 \mathrm{~b}$ propose a positive relationship between negative deviation from prior performance and board attention to monitoring, and a negative relationship between positive deviation from prior performance and board attention to monitoring, respectively. The accurate interpretation of the coefficient for negative deviation requires careful interpretation. When dealing exclusively with negative numbers, such as those represented by negative deviation from prior performance, a negative sign on the coefficient indicates that greater deviation leads to higher levels of attention to monitoring. Thus, a statistically significant negative coefficient is required to support Hypothesis 1a. As seen in Models 3a and 3b, negative deviation from prior performance is negative and statistically 


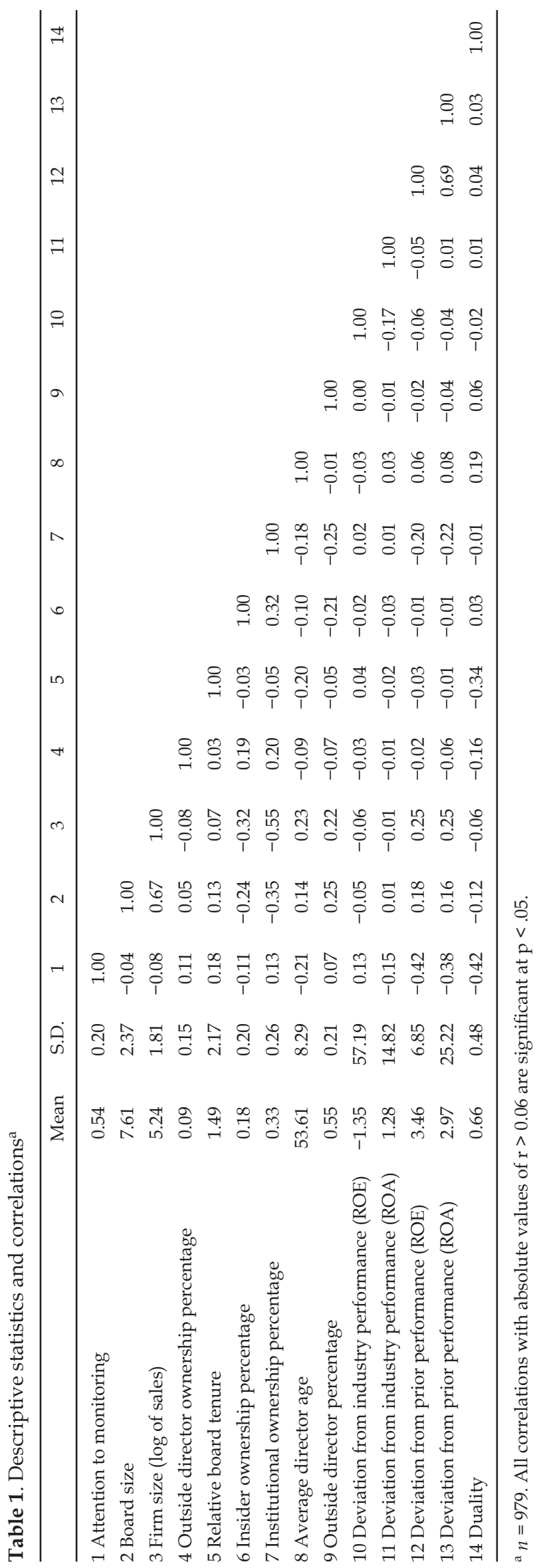

significant. These results are also demonstrated in Models 2a, 2b, 4a and 4b. Thus, Hypothesis $1 \mathrm{a}$ is supported.

Whereas negative deviation from prior performance requires careful interpretation, positive deviation from prior performance is more straightforward. Support for Hypothesis $1 \mathrm{~b}$ requires the sign of the coefficient to follow the hypothesized direction, which in this case is negative. As seen in Models $3 a$ and $3 b$, positive deviation from prior performance is negative and significant in both models. Again, these results are robustly demonstrated in the Models 2a, 2b, 4a, and $4 \mathrm{~b}$. Thus Hypothesis $1 \mathrm{~b}$ is supported. Graphs depicting the results for Hypotheses $1 \mathrm{a}$ and $1 \mathrm{~b}$ are provided in Figures 1 and 2.

Hypothesis 2 predicts that the effect of negative deviation from prior performance on the board's attention to monitoring is greater than the effect of positive deviation. Tests of differences between the two coefficients show that they are statistically different and that negative deviation has a greater effect (for Model 2a: $F=90.45, p<0.000$; Model 2b: $F=85.05$, $p<0.000)$. Likewise, Greve's (2003) approach offers support. Specifically, Models $2 \mathrm{a}$ and $2 \mathrm{~b}$ reveal the coefficients of positive deviation are between zero and their respective coefficient estimates for negative deviation. Thus Hypothesis 2 is supported. Hypothesis 3 posits that CEO duality is negatively related to board attention to monitoring. As seen in Models 3a and $3 b, C E O$ duality is negative and statistically significant in both models. Finally, these results are also robustly demonstrated in Models 2a, 2b, 4a, and $4 \mathrm{~b}$. Thus, Hypothesis 3 is supported.

Models $4 \mathrm{a}$ and $4 \mathrm{~b}$ in Table 2 report the tests of Hypotheses $4 \mathrm{a}$ and $4 \mathrm{~b}$. Hypothesis $4 \mathrm{a}$ predicts that duality will moderate the relationship between negative deviation from prior performance and board attention to monitoring such that the presence of CEO duality will weaken the relationship. Thus, a positive sign for this interaction term is required to support this hypothesis. As seen in Models $4 \mathrm{a}$ and $4 \mathrm{~b}$, the interaction term is positive and statistically significant. Thus Hypothesis 4a is supported.

Hypothesis $4 \mathrm{~b}$ posits that CEO duality moderates the relationship between positive deviation from prior performance and board attention to monitoring such that duality amplifies the relationship. Support of this hypothesis requires a negative interaction term. While insignificant for the ROA model, the in- 


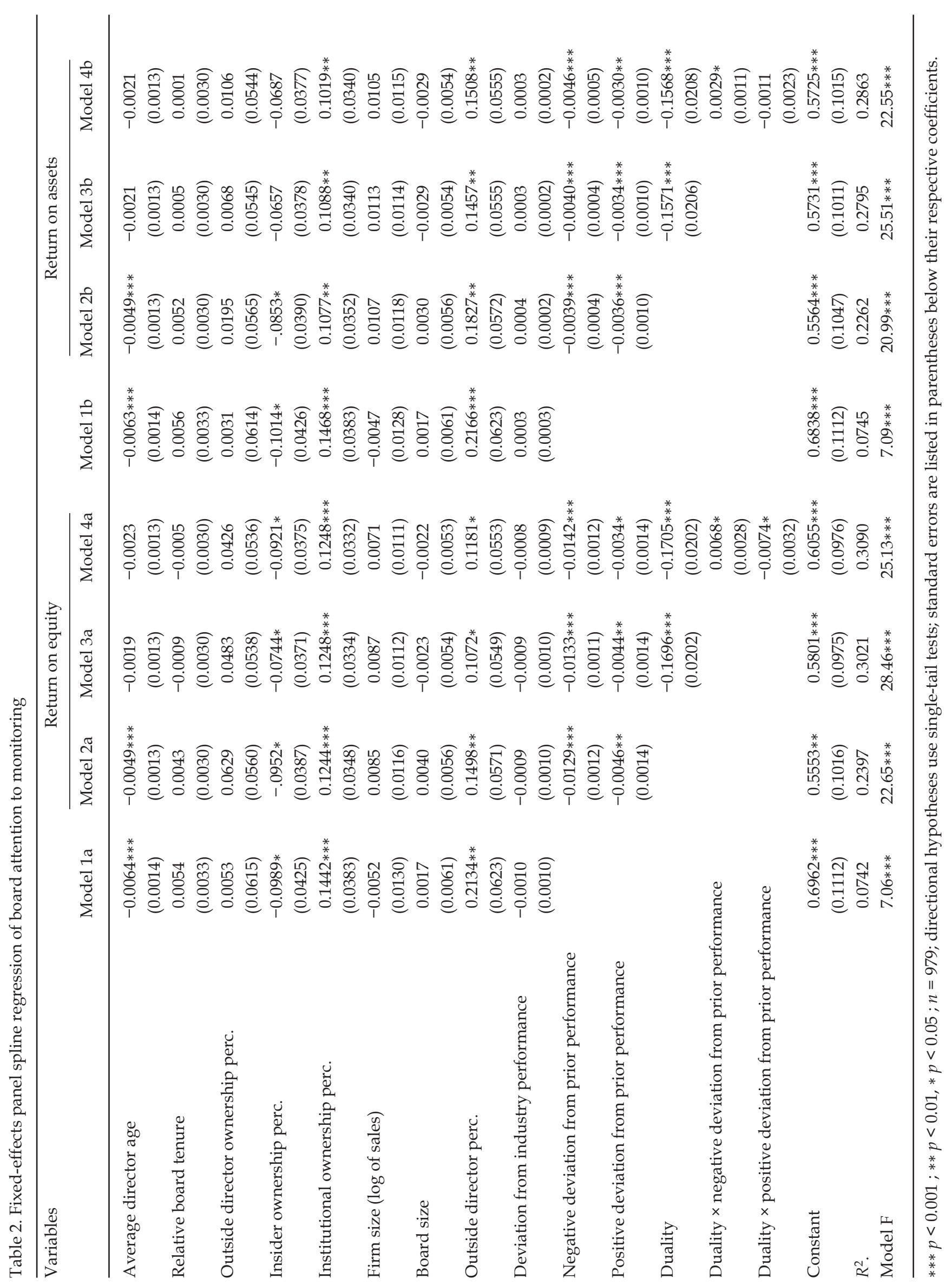




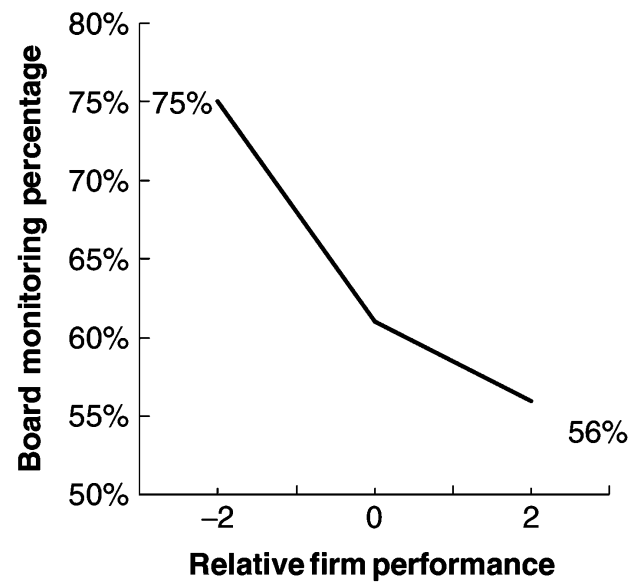

Figure 1. Effects of negative and positive deviation from prior performance (ROE)

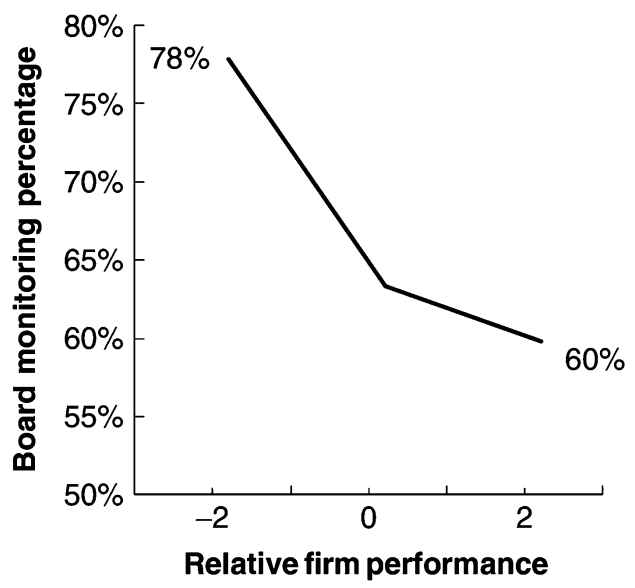

Figure 2. Effects of negative and positive deviation from prior performance (ROA)

teraction term in the ROE model was negative and statistically significant. Thus, Hypothesis $4 \mathrm{~b}$ is partially supported. ${ }^{7}$

As briefly mentioned above, it is worthwhile to note that the primary first-order (noninteraction) variables of interest in the study remain substantively unchanged in Models $4 \mathrm{a}$ and $4 \mathrm{~b}$ as compared with Models 2-3b. However, when interaction terms are present in a model, the first-order variable's coefficients indicate conditional effects, as opposed to general or main effects (Jaccard, Turrisi, and Wan, 1990). That is, they demonstrate the effect of the primary variable on the outcome of interest when the product term is zero (a condition created when the moderat-

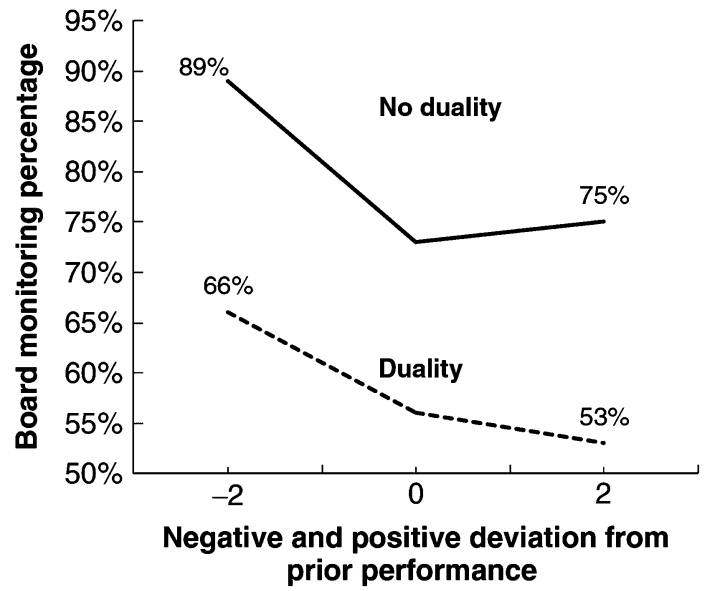

Figure 3. Interactive effects of deviations from prior performance and duality (ROE)

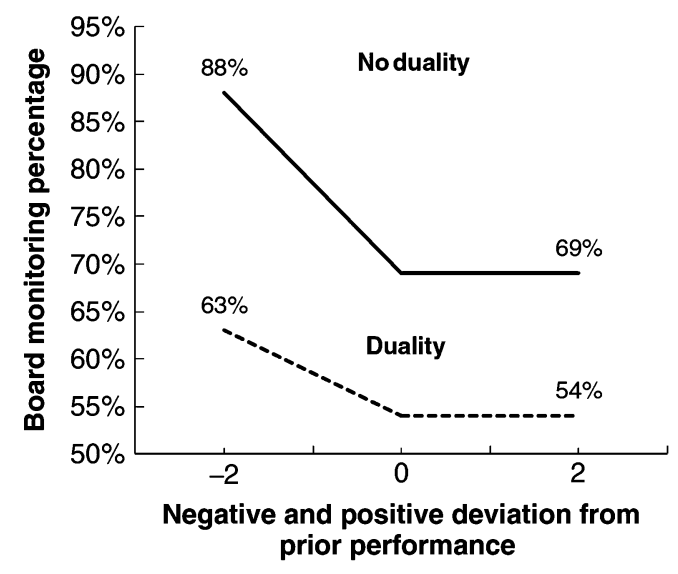

Figure 4. Interactive effects of deviations from prior performance and duality (ROA)

ing variable equals zero). Aiken and West (1991) suggest graphs based on simple slopes are the preferred means of depicting the results of regression models that include interaction terms. Graphs depicting the results from Models $4 \mathrm{a}$ and $4 \mathrm{~b}$ are presented as Figures 3 and 4 . Both figures show the effect of duality on the relationship between deviation from prior performance and attention to monitoring. Most striking is that duality reduces the overall level of attention to monitoring (i.e., an intercept effect). Next, duality reduces the strength of the relationship between negative deviation and monitoring (i.e., a slope effect). On the other hand, only Figure 3 shows the effect of duality on the relationship between positive deviation

7. Results are robust when measuring prior performance relative to a firm's prior three-year average and relative to a firm's prior year. 
from prior performance and monitoring. In the presence of duality, the negative relationship between positive deviation and monitoring is stronger (i.e., a slope effect). Interestingly, this figure also shows that without duality, monitoring increases with positive deviation from prior performance.

\section{Discussion}

Researchers from a variety of academic fields have sought to better understand corporate governance. We add to this research stream by investigating antecedents of boards' attention to their central function: monitoring (Hillman and Dalziel, 2003). Understanding how boards allocate their attention is important because, as the ABV argues, attention precedes actions (Ocasio, 1997). Thus, if monitoring behavior is desired, board members' attention must first be allocated to monitoring. However, unlike board research based on an agency perspective, which assumes, if implicitly, that board members are rational (Cyert and March, 1992), we argue that, like other decision makers (e.g., top managers), board members possess significant limitations in information processing (Ocasio, 1997; Simon, 1947). As such, board members do not attend equally to all matters, even issues that may merit such attention, but instead selectively allocate attention to issues deemed important (Ocasio, 1997). According to the $\mathrm{ABV}$, selective attention allocation is determined by contextual and structural factors relevant to the actors. Thus, we argued that deviation from prior performance (contextual factor) and duality (structural factor) are especially relevant in board members' allocation of attention to monitoring. Our results support our theoretical logic and provide several contributions to theory and practice.

Perhaps most importantly, we found that, indeed, boards' allocation of attention to monitoring varies. ${ }^{8}$ The results of all the hypotheses tests, based on data obtained by analyzing hundreds of detailed transcripts of actual board meetings, make this finding quite robust. In sum, this means that boards do not maintain constant levels of attention to monitor- ing, but instead attend selectively to their monitoring function among other functions, based on contextual and structural factors. Importantly, these results were obtained in models where independence and other indicators of board vigilance, along with other contextual factors, were included. Thus, attention to monitoring is based on more than demographic or composition variables - it involves the engagement of board members (Hillman et al., 2008).

Beyond supporting the ABV's basic tenets within boards, our findings also demonstrate prospect theory's applicability to corporate boards. In support of prospect theory, where deviation from prior performance was identified as a key contextual factor to monitoring behavior, we found that negative deviation from prior performance leads to higher allocation of attention to monitoring, whereas positive deviation leads to lower allocations of attention to monitoring. Moreover, the effects of negative and positive deviation were not equal: negative deviation had a greater effect on changes in the attention paid to monitoring than did positive deviation.

These findings suggest that positive performance may lead to a weakness in corporate governance, at least as far as boards are concerned. Because many large-scale projects and proposals that boards evaluate are long-term in nature, if these plans are presented and discussed by the board when performance is increasing, they may not be scrutinized at levels needed to fully understand their potential long-term effects on shareholder wealth. That is, when performance is increasing and monitoring decreases, management may be able to divert boards' attention and concerns more easily-a proposition the Rockefeller family has recently raised in the context of the ExxonMobil Corporation. Similarly, this outcome might shed light on the crises faced by Citigroup (Editorial, 2008), Ford, AIG, and other companies caught in the recent global financial tsunami (Lublin, 2008). Of course, increased director monitoring in times of performance declines may be too late owing to time compression and related diseconomies (Dierickx and Cool, 1989).

This study also extends research on board structure by considering the impact of CEO duality on

8. It's important to note that prior agency-based research finds that various control mechanisms may substitute or complement one another (i.e., Finkelstein and D'Aveni, 1994; Morck et al., 1989; Rediker and Seth, 1995; Sundaramurthy, 1996; Sundaramurthy, Mahoney, and Mahoney, 1997). More specifically related to this study, Beatty and Zajac (1994), Rediker and Seth (1995), and Rutherford, Buchholtz, and Brown (2007) find that boards often utilize managerial incentives as a means to mitigate agency concerns. These incentives (e.g., compensation, stock ownership, etc.) may serve as a, most likely partial, substitute for board monitoring. 
boards' allocation of attention to monitoring. We draw on the power and politics literature to argue that duality reduces board members' allocation of attention to monitoring. In support, we found that duality leads to lower allocations of attention to monitoring. This suggests that the reason the literature lacks findings for a monitoring-performance relationship (Dalton et al., 2007) may be that the relationship is more sophisticated than generally assumed (Daily, Dalton, and Rajagopalan, 2003b). For instance, we see that performance affects monitoring, which may in turn affect future performance via the boards' influence on CEO turnover, resource provision, influence on strategy, and others. Such intervening factors offer promising directions for future research. In total, this finding provides the basis for investigating more elaborate relationships between duality and firm performance.

Continuing our investigation of deviation from prior performance and duality, we considered the interactive effects of these two variables on the boards' allocation of attention to monitoring. In three of four tests, our results show lationship between the deviation from prior perfor that duality moderates the remance and attention to monitoring. Specifically, we see that duality weakens the relationship between negative deviation from prior performance and the boards' attention to monitoring. This finding suggests that when faced with the threat of poor performance, CEO-chairs utilize their power to combat the natural tendency of boards to increase attention to monitoring.

The results are less clear regarding duality's moderation of the relationship between positive deviation from prior performance and attention to monitoring. No relationship was found when performance was measured by ROA. However, in the ROE model, we see that duality amplifies the negative relationship. In total, these two results suggest that CEO-chairs may use their power less frequently when performance is increasing. In both cases, however, as seen in Figures 3 and 4 , there is a strong effect on the intercept of the boards' attention to monitoring.

Duality's direct and interactive effects suggest it is an important antecedent to effective board function. In fact, combining duality with positive performance deviation may lead to unacceptably low levels of board attention to monitoring, which may undermine the protection of shareholders' interests. On the other hand, the high levels of board attention to monitoring in firms without duality and facing performance declines might yield "too much" oversight; CEOs might feel unsupported (e.g., constantly questioned) and thus delay taking necessary, yet risky, actions.

Finally, after we found support for our dualityattention to monitoring hypothesis (Hypothesis 3), we conducted several post hoc analyses to investigate the ways in which duality may affect boards' attention to monitoring. Specifically, we posited that a chairperson can have substantial influence over the agenda of board meetings (Finkelstein and D'Aveni, 1994), a factor Ocasio (1997) suggests will affect committee members' allocation of attention. By designing and implementing more detailed, rigid agendas, CEO-chairs can focus the attention of boards on topics that suit their own interests and away from monitoring issues. Our test supports this relationship. Specifically, in a duality-only subsample, a model including all control variables along with a categorical variable operationalizing agenda detail, we found that agenda detail was significantly and negatively related to board discussions of monitoring issues. This aids our understanding of one important way duality may affect boards' attention to monitoring.

Next, we thought that holding board meetings in venues other than the corporate boardroom might limit board attention to monitoring for two reasons. First, research shows that variety in environmental stimuli consume individuals' limited attentional capacity (Russell and Ward, 1982). Second, by convening meetings in off-site locations, which are often at least semi-recreational in nature, CEO-chairs may ingratiate themselves to corporate board members, creating norms of reciprocity (Gouldner, 1960) that favor support of the CEO-chair (Westphal and Stern, 2007a, 2007b). Our tests suggest that CEO-chairs may use off-site meetings to limit boards' attention to monitoring. Using models similar to those used to examine the effects of agenda setting, we find that the percentage of annual offsite board meeting time is significantly and negatively related to the amount of board meeting discussion allocated to monitoring issues. This gives us a glimpse of yet another avenue through which CEO duality may affect boards' attention to monitoring. 


\section{Limitations and future research}

This study contributes to a growing body of research (e.g., Westphal and Khanna, 2003; Westphal and Zajac, 1997) that sheds light into the "black box" of board functioning; however it would be useful for future work to supplement board transcripts with other sources of data related to director behavior. For example, supplementing board transcript data with discussions occurring in separate committee meetings or even outside of the boardroom proper would contribute additional understanding of board monitoring behavior. It may be, however, that some monitoring behavior is purely cognitive, with no record available. Second, not being able to quantify social relationships among the board members limits these data. Third, the focus on U.S. firms in our sample may represent another potential limitation; future research may further contribute to our understanding of board monitoring by conducting similar studies with a more globalized sample. Fourth, while we measured the quantity of board attention to monitoring, the quality of board attention to monitoring was not assessed. Though board attention to monitoring is necessary for effective board governance, it is not sufficient. Finally, while the diverse industries examined allow for generalization of our findings, this generalizability may not extend to small firms. Few small firms had board transcripts detailed enough for analysis.

\section{Conclusion}

What factors influence boards of directors' allocation of attention to monitoring is an important question facing corporate governance researchers and practitioners, particularly in today's economic environment. Our analysis of actual transcripts of hundreds of board meetings demonstrates that board members selectively attend to monitoring depending on the firms' deviation from prior performance and whether duality is present. Our findings may assist stakeholders in devising mechanisms that ensure shareholder interests are upheld more consistently.

Acknowledgments - We thank Ed Zajac and two anonymous reviewers for their comments and help in developing this paper. We also thank Amy Hillman and Mason Carpenter for providing valuable feedback. A previous version of this work was presented at the 2008 Academy of Management meeting and included in the meeting's Proceedings.

\section{References}

Abrahamson E, Park C. 1994. Concealment of negative organizational outcomes: an agency theory perspective. Academy of Management Journal 37(5): 1302-1334.

AICPA. 1988. AICPA Code of Professional Conduct. American Institute of Certified Public Accountants: Jersey City, NJ.

Aiken LS, West SG. 1991. Multiple Regression : Testing and Interpreting Interactions. Sage Publications: London, UK.

Audia PG, Greve HR. 2006. Less likely to fail: low performance, firm size, and factory expansion in the shipbuilding industry. Management Science 52(1): 83-94.

Baliga BR, Moyer RC, Rao RS. 1996. CEO duality and firm performance: what's the fuss? Strategic Management Journal 17(1): 41-53.

Barnett ML. 2008. An attention-based view of real options reasoning. Academy of Management Review 33(3): 606-628.

Barr PS. 1998. Adapting to unfamiliar environmental events: a look at the evolution of interpretation and its role in strategic change. Organization Science 9(6): 644-669.

Beatty RP, Zajac EJ. 1994. Managerial incentives, monitoring, and risk bearing: a study of executive-compensation, ownership, and board structure in initial public offerings. Administrative Science Quarterly 39(2): 313-335.

Bouquet C, Birkinshaw J. 2008. Weight versus voice: how foreign subsidiaries gain attention from corporate headquarters. Academy of Management Journal 51(3): 577-601.

Bowen HP, Wiersema MF. 1999. Matching method to paradigm in strategy research: limitations of cross-sectional analysis and some methodological alternatives. Strategic Management Journal 20(7): 625-636.

Bowman E. 1984. Content analysis of annual reports for corporate strategy and risk. Interfaces 14: 61-71.

Boyd BK. 1995. CEO duality and firm performance: a contingency model. Strategic Management Journal 16(4): 301-312.

Brickley JA, Coles JL, Jarrell G. 1997. Leadership structure: separating the CEO and chairman of the board. Journal of Corporate Finance 3: 189-220.

Cannella AA Jr., Lubatkin M. 1993. Succession as a sociopolitical process: internal impediments to outsider selection. Academy of Management Journal 36(4): 763-793.

Chen MJ, Hambrick DC. 1995. Speed, stealth, and selective attack: how small firms differ from large firms in competitive behavior. Academy of Management Journal 38(2): 453-482.

Chen MJ, Macmillan I. 1992. Nonresponse and delayed response to competitor moves: the roles of competitor dependence and action irreversibility. Academy of Management Journal 35: 539-570.

Chen MJ, Miller D. 1994. Competitive attack, retaliation and performance: an expectancy-valence framework. Strategic Management Journal 15(2): 85-102. 
Cho TS, Hambrick DC. 2006. Attention as the mediator between top management team characteristics and strategic change: the case of airline deregulation. Organization Science 17(4): 453-469.

Clapham SE, Schwenk CR. 1991. Self-serving attributions, managerial cognition, and company performance. Strategic Management Journal 12(3): 219-229.

Clark A. 2008. Myopic ExxonMobil is ignoring the planet's future, say Rockefellers. Guardian (United Kingdom), 1 May.

Coles JW, McWilliams VB, Sen N. 2001. An examination of the relationship of governance mechanism to performance. Journal of Management 27: 23-50.

Conyon MJ, Peck SI. 1998. Board control, remuneration committees, and top management compensation. Academy of Management Journal 41(2): 146-157.

Cyert RM, March JG. 1992. A Behavioral Theory of the Firm (2nd edn). Wiley-Blackwell: Oxford, UK.

Dahya J, McConnell JJ. 2005. Outside directors and corporate board decisions. Journal of Corporate Finance 11(1-2): 37-60.

Daily CM, Dalton DR, Cannella AA Jr. 2003a. Corporate governance: decades of dialogue and data. Academy of Management Review 28(3): 371-381.

Daily CM, Dalton DR, Rajagopalan N. 2003b. Governance through ownership: centuries of practice, decades of research. Academy of Management Journal 46(2): 151-158.

Dalton DR, Daily CM, Ellstrand AE, Johnson JL. 1998. Metaanalytic reviews of board composition, leadership structure, and financial performance. Strategic Management Journal 19(3): 269-290.

Dalton DR, Hitt MA, Certo ST, Dalton CM. 2007. The fundamental agency problem and its mitigation: independence, equity, and the market for corporate control. In Academy of Management Annals (Volume 3), Brief A, Walsh J (eds). Routledge: London, UK; 1-64.

D'Aveni RA, Macmillan IC. 1990. Crisis and the content of managerial communications: a study of the focus of attention of top managers in surviving and failing firms. Administrative Science Quarterly 35(4): 634-657.

Davidson WN, Jiraporn P, Kim YS, Nemec C. 2004. Earnings management following duality-creating successions: ethnostatistics, impression management, and agency theory. Academy of Management Journal 47(2): 267-275.

Dierickx I, Cool K. 1989. Asset stock accumulation and sustainability of competitive advantage. Management Science 35(12): 1504-1511.

Editorial. 2008. Citi's taxpayer parachute. Wall Street Journal, 25 November 25; A14.

Eisenhardt KM. 1989. Agency theory: an assessment and review. Academy of Management Review 14: 57-74.

Fama EF. 1980. Agency problems and the theory of the firm. Journal of Political Economy 88: 288-307.
Fama EF, Jensen MC. 1983a. Agency problems and residual claims. Journal of Law and Economics 26: 325-350.

Fama EF, Jensen MC. 1983b. Separation of ownership and control. Journal of Law and Economics 26: 301-325.

Finkelstein S, D’Aveni RA. 1994. CEO duality as a doubleedged sword: how boards of directors balance entrenchment avoidance and unity of command. Academy of Management Journal 37(5): 1079-1108.

Finkelstein S, Hambrick DC. 1996. Strategic Leadership: Top Executives and their Effects on Organizations( West's Strategic Management Series). West: Minneapolis/St. Paul, MN.

Finkelstein S, Hambrick DC, Cannella AA. 2009. Strategic Leadership: Theory and Research on Executives, Top Management Teams, and Boards. Oxford University Press: New York.

Fredrickson JW, Hambrick DC, Baumrin S. 1988. A model of CEO dismissal. Academy of Management Review 13(2): 255-270.

Gibbons R, Murphy KJ. 1990. Relative performance evaluation for chief executive office. Industrial and Labor Relations Review 43: 30-51.

Gladstein D. 1984. Groups in context: a model of task group effectiveness. Administrative Science Quarterly 29: 499-517.

Gold R, Eaton L. 2008. Exxon email opposes shareholder measure. Wall Street Journal, 13 May; B4.

Gouldner AW. 1960. The norm of reciprocity: a preliminary statement. American Sociological Review 25(2): 161-178.

Goyal VK, Park CW. 2002. Board leadership structure and CEO turnover. Journal of Corporate Finance 8(1): 49-66.

Greene WH. 2002. Econometric Analysis (5th edn). PrenticeHall: Upper Saddle River, NJ.

Greve HR. 1998. Performance, aspirations, and risky organizational change. Administrative Science Quarterly 43(1): 58-86.

Greve HR. 2003. A behavioral theory of R\&D expenditures and innovations: evidence from shipbuilding. Academy of Management Journal 46(6): 685-702.

Haleblian J, Finkelstein S. 1993. Top management team size, CEO dominance, and firm performance: the moderating roles of environmental turbulence and discretion. Academy of Management Journal 36(4): 844-863.

Hambrick DC, Jackson EM. 2000. Outside directors with a stake: the linchpin in improving governance. California Management Review 42(4): 108-127.

Hermalin BE. 2005. Trends in corporate governance. Journal of Finance 60(5): 2351-2384.

Hillman AJ, Dalziel T. 2003. Boards of directors and firm performance: integrating agency and resource dependence perspectives. Academy of Management Review 28(3): 383-396.

Hillman AJ, Nicholson G, Shropshire C. 2008. Directors' multiple identities, identification, and board monitoring and resource provision. Organization Science 19(3): 441-456. 
Hitt MA, Gimeno J, Hoskisson RE. 1998. Current and future research methods in strategic management. Organizational Research Methods 1(1): 6-44.

Hoskisson RE, Hitt MA, Johnson RA, Grossman W. 2002. Conflicting voices: the effects of institutional ownership heterogeneity and internal governance on corporate innovation strategies. Academy of Management Journal 45(4): 697-716.

Huff AS. 1990. Mapping Strategic Thought. Wiley: Chichester, UK.

Jaccard J, Turrisi R, Wan CK. 1990. Interaction Effects in Multiple Regression. Sage: Newbury Park, CA.

Jensen MC, Meckling WH. 1976. Theory of the firm: managerial behavior, agency costs and ownership structure. Journal of Financial Economics 3: 305-360.

Johnson JL, Daily CM, Ellstrand AE. 1996. Boards of directors: a review and research agenda. Journal of Management 22(3): 409-438.

Judge WQ, Zeithaml CP. 1992. Institutional and strategic choice perspectives on board involvement in the strategic decision process. Academy of Management Journal 35: 766-794.

Kahneman D, Tversky A. 1979. Prospect theory: an analysis of decision under risk. Economerica 47: 313-327.

Kaplan S. 2008. Cognition, capabilities, and incentives: assessing firm response to the fiber-optic revolution. Academy of Management Journal 51(4): 672-695.

Krauss C. 2008. Rockefellers seek change at Exxon. New York Times, 27 May; C6.

Krippendorff K. 2004. Content Analysis: An Introduction to its Methodology. Sage: Beverly Hills, CA.

Kroll M, Walters BA, Wright P. 2008. Board vigilance, director experience, and corporate outcomes. Strategic Management Journal 29(4): 363-382.

Lublin JS. 2008. As firms flounder, directors quit. Wall Street Journal, 11 November; B1.

Lukes S. 1974. Power: A Radical view. Macmillan: London, UK.

Mace ML. 1971. Directors: Myth and Reality. Harvard Business School Press: Boston, MA.

Mallette P, Fowler KL. 1992. Effects of board composition and stock ownership on the adoption of 'poison pills.' Academy of Management Journal 35: 1010-1035.

Marsh LC, Cormier DR. 2002. Spline Regression Models. Sage: Thousand Oaks, CA.

McDonald ML, Westphal JD. 2003. Getting by with the advice of their friends: CEOs' advice network and firms' strategic responses to poor firm performance. Administrative Science Quarterly 48(1): 1-32.

Milgrom P, Roberts J. 1992. Economics, Organization and Management. Prentice Hall: Englewood Cliffs, NJ.

Monks RAG, Minow N. 2004. Corporate Governance (3rd edn). Blackwell Publishing: Malden, MA.
Morck R, Shleifer A, Vishny RW. 1989. Alternative mechanisms for corporate control. American Economic Review 79(4): 842-852.

Morrow JL, Sirmon DG, Hitt MA, Holcomb TR. 2007. Creating value in the face of declining performance: firm strategies and organizational recovery. Strategic Management Journal 28(3): 271-283.

Mufson S. 2008. Rebuffing the Rockefellers. Washington Post, 29 May.

Neter J, Wasserman N, Kutner MH. 1985. Applied Linear Statistical Models: Regression, Analysis of Variance and Experimental Designs. Irwin: Homewood, IL.

Ocasio W. 1997. Towards an attention-based view of the firm. Strategic Management Journal, Summer Special Issue 18: 187-206.

Pettigrew AM. 1992. The character and significance of strategy process research. Strategic Management Journal, Winter Special Issue 13: 5-16.

Pfeffer J. 1981. Power in Organizations. Pitman: Boston, MA.

Pfeffer J. 1992. Managing with Power: Politics and Influence in Organizations. Harvard Business School Press: Boston, MA.

Rechner PL, Dalton DR. 1989. The impact of CEO as board chairperson on corporate performance: evidence vs. rhetoric. Academy of Management Executive 3(2): 141-143.

Rediker KJ, Seth A. 1995. Boards of directors and substitution effects of alternative governance mechanisms. Strategic Management Journal 16(2): 85-99.

Russell JA, Ward LM. 1982. Environmental psychology. Annual Review of Psychology 33: 651-688.

Rutherford MA, Buchholtz AK, Brown JA. 2007. Examining the relationships between monitoring and incentives in corporate governance. Journal of Management Studies 44(3): 414-430.

Sapir E. 1944. Grading: a study in semantics. Philosophy of Science 11: 93-116.

Sayrs LW. 1989. Pooled Time Series Analysis (Quantitative Applications in the Social Sciences). Sage: Newbury Park, CA.

Shimizu K. 2007. Prospect theory, behavioral theory, and the threat-rigidity thesis: combinative effects on organizational decisions to divest formerly acquired units. Academy of Management Journal 50(6): 1495-1514.

Simon HA. 1947. Administrative Behavior: A Study of Decisionmaking Processes in Administrative Organizations. Macmillan: Chicago, IL.

Sirmon DG, Gove S, Hitt MA. 2008. Resource management in dyadic competitive rivalry: the effects of resource bundling and deployment. Academy of Management Journal 51(5): 919-935.

Sirmon DG, Hitt MA. 2009. Contingencies within dynamic managerial capabilities: interdependent effects of resource investment and deployment on firm performance. Strategic Management Journal 30(13): 1375-1394. 
Sirmon DG, Hitt MA, Arregle J-L, Campbell JT. Forthcoming. Capability Strengths and Weaknesses in Dynamic Markets: Investigating the Bases of Temporary Competitive Advantage. Strategic Management Journal, in press.

Sirmon DG, Hitt MA, Ireland RD. 2007. Managing firm resources in dynamic environments to create value: looking inside the black box. Academy of Management Review 32(1): 273-292.

Sonpar K, Golden-Biddle K. 2008. Using content analysis to elaborate adolescent theories of organization. Organizational Research Methods 11(4): 795-814.

Srinivasan S, Richardson SA. 2005. Consequences of financial reporting failure for outside directors: evidence from accounting restatements and audit committee members. Journal of Accounting Research 43(2): 291-342.

Sundaramurthy C. 1996. Corporate governance within the context of antitakeover provisions. Strategic Management Journal 17(5): 377-394.

Sundaramurthy C, Mahoney JM, Mahoney JT. 1997. Board structure, antitakeover provisions, and stockholder wealth. Strategic Management Journal 18(3): 231-245.

Tuggle CS, Schnatterly K, Johnson RA. 2010. Attention patterns in the boardroom: how board composition and processes affect discussion of entrepreneurial issues. Academy of Management Journal 53(3): in press.

Tversky A, Kahneman D. 1981. The framing of decisions and the psychology of choice. Science 211(4481): 453-458.

Tversky A, Kahneman D. 1992. Advances in prospect theory: cumulative representation of uncertainty. Journal of Risk and Uncertainty 5(4): 297-323.

Walsh JP, Seward JK. 1990. On the efficiency of internal and external corporate control mechanisms. Academy of Management Review 15: 421-458.

Westphal JD. 1998. Board games: how CEOs adapt to increases in structural board independence from management. Administrative Science Quarterly 43(3): 511-537.

Westphal JD, Fredrickson JW. 2001. Who directs strategic change? Director experience, the selection of new CEOs, and change in corporate strategy. Strategic Management Journal 22(12): 1113-1137.

Westphal JD, Khanna P. 2003. Keeping directors in line: social distancing as a control mechanism in the corporate elite. Administrative Science Quarterly 48(3): 361-398.

Westphal JD, Stern I. 2007a. Flattery will get you everywhere (especially if you are a male caucasian): how ingratiation, boardroom behavior, and demographic minority status affect additional board appointments at U.S. companies. Academy of Management Journal 50(2): 267-288.

Westphal JD, Stern I. 2007b. The other pathway to the boardroom: interpersonal influence behavior as a substitute for elite credentials and majority status in obtaining board appointments. Administrative Science Quarterly 51(2): 169204. Westphal JD, Zajac EJ. 1997. Defections from the inner circle: social exchange, reciprocity, and the diffusion of board independence in U.S. corporations. Administrative Science Quarterly 42(1): 161-183.

Westphal JD, Zajac EJ. 1998. The symbolic management of stockholders: corporate governance reforms and shareholder reactions. Administrative Science Quarterly 43(1): 127-153.

Whorf BL. 1956. Science and linguistics. In Language, Thought and Reality: Selected Writings of Benjamin Lee Whorf, Carroll JB (ed). MIT Press: Cambridge, MA; 207-219.

Williamson OE. 1988. Corporate finance and corporate governance. Journal of Finance 43: (July): 567-591.

Wiseman RM, Gomez-Mejia LR. 1998. A behavioral agency model of managerial risk taking. Academy of Management Review 23(1): 133-153.

Wright P, Kroll M, Elenkov D. 2002. Acquisition returns, increase in firm size, and chief executive officer compensation: the moderating role of monitoring. Academy of Management Journal 45(3): 599-608.

Yadav MS, Prabhu JC, Chandy RK. 2007. Managing the future: CEO attention and innovation outcomes. Journal of Marketing 71(4): 84-101.

Young G, Smith KG, Grimm CM. 1996. "Austrian"' and industrial organization perspectives on firm-level competitive activity and performance. Organization Science 7(3): 243-254.

Yu JS, Engleman RM, Van de Ven AH. 2005. The integration journey: an attention-based view of the merger and acquisition integration process. Organization Studies 26(10): 1501-1528.

Zahra SA, Neubaum DO, Huse M. 2000. Entrepreneurship in medium-size companies: exploring the effects of ownership and governance systems. Journal of Management 26(5): 947-976.

Zahra SA, Pearce JA. 1989. Boards of directors and corporate financial performance: a review and integrative model. Journal of Management 15(2): 291-334.

Zajac EJ, Westphal JD. 1994. The costs and benefits of managerial incentives and monitoring in large U.S. corporations: when is more not better. Strategic Management Journal, Winter Special Issue 15: 121-142.

Zajac EJ, Westphal JD. 1996. Director reputation, CEO-board power, and the dynamics of board interlocks. Administrative Science Quarterly 41(3): 507-529.

Zald MN. 1969. Power and functions of boards of directors: theoretical synthesis. American Journal of Sociology 75(1): 97-111. 


\section{Appendix A: Obtaining Board Transcripts Sample}

In collecting board transcript data for this study, we implemented the following three design procedures: (1) we ensured firm and director confidentiality and risk-free participation, (2) we elicited participation of sample firms' respective auditing firms, and (3) we organized auditing firms' certified professional accountants (CPAs) as coders. A more detailed description of these procedures is outlined in the following sections.

\section{Firm participation in sample}

First, we contacted 1,894 firms to request their participation in a research program focusing on board of director discussions. In many cases, firm records managers (often attorneys) expressed reluctance to allow their board meeting transcripts outside their firm. To overcome this problem, we requested that the firm's auditors, who already have read and currently have access to board transcripts as part of the firm's required annual audit, code the firm's board transcripts regarding the discussion of monitoring behaviors. Auditors are bound by the American Institute of Certified Public Accountants' Code of Professional Conduct, of which rule 301 states that '[a] member in public practice shall not disclose any confidential client information without the specific consent of the client' (AICPA, 1988: ET Section 301.01).

To further assure participating sample firms of the risk-free nature of their participation, confidentiality agreements were offered to each firm specifying firm and director anonymity. Also, the time sensitivity of board discussions was considered. Though the initial data-gathering phase of this research was conducted in late 2003, the sample coding was stopped at fiscal yearend 2000. Twenty-one percent, or 398, of the firms contacted agreed to participate in this study and had board transcripts of sufficient quality to undergo coding. Of the 398 firms that agreed to participate, only 210 had board meeting transcripts with sufficient detail for the purposes of this study. ${ }^{9}$ Additionally, 32 firms from this 210 were eliminated from our ultimate sample of 178 firms due to an error in CPA coding for this project.

\section{Auditing firm participation}

CPAs of the public accounting firms that performed the audits of our sample firms during our sample period were utilized as coders. We requested each auditing firm's participation in this study once a sample firm agreed to participate.

The sample firms' auditors have unique access to company board transcripts, which makes them an appealing conduit to board transcript coding. Auditing firms deliver an opinion on a company's financial statements based on their audit of the firm's current accounting cycle (typically one year). In doing so, the auditors compile supporting documents at each stage of the annual audit. These documents are referred to as 'current workpapers' and are retained in a 'current' file by the auditors. If documents apply to a company's longer-term (typically more than one year) concerns, then these documents are retained in a file referred to as a 'permanent file.' Examples of current file documents are as follows: verification of a random sample of current-year sales receipts, verification of separation of controls, and review of investments made in the last year over a material amount. Examples of permanent file documents include the following: organizational structure of the firm, copies of important legal documents, copies of long-term loans, and board transcripts.

While not all auditing firms follow the same auditing procedures and retention policies, board transcripts are, by auditing convention, retained in the auditor's permanent file. Thus, for our sample firms, board transcripts were available for years 1994-2000 unless the firm discontinued operation. Also contributing to this study's time period selection was the auditors' implementation of retaining copies of board transcripts electronically. Because electronic versions of files are less expensive to retain than hard copies, auditors typically have word processing copies of these files from 1994 onward.

Also, we were able to accommodate the busy schedules of the auditing firms. The reviewing and

9. We tested for director-level and firm-level characteristic differences between participating firms that had detailed enough minutes to be included in this study's sample and firms that did not. Using the Kolmogorov-Smirnov test, no significant differences were found. 
coding of board transcripts by CPAs was coordinated to accommodate the auditors' schedules. The majority of this study's coding took place in the months of November and December 2003, which is typically a time period when auditing firms experience a lull in their business.

\section{Organization of CPAs}

Assignment of CPA coders and the coding procedures are explained in Appendix B. Coordination of the auditing firm coding and payment of the audit firms for their services are detailed in this subsection. The 178 sample companies (979 company-years) audits were performed by one of, or a combination of, six national auditing firms and two regional auditing firms for this study's time frame. Combinations of auditing firms occurred when the sample company changed auditing firms by preference or by necessity. Over the sample and data collection periods, two major changes occurred within the U.S. accounting industry. In 1998, Price Waterhouse and Coopers \& Lybrand accounting firms merged into Price Waterhouse Coopers. Also, in August 2002, Arthur Anderson agreed to surrender its CPA licenses and its right to practice before the Securities and Exchange Commission. In both of these instances, board transcripts for our sample companies were transferred to the new auditors as part of the overall audit materials.

As detailed in Appendix B, various amounts of coding time were necessary for each set of annual board minutes. Payment varied depending on the time spent and the price agreed upon with each auditing firm. These prices were negotiated at the auditing office level, not the national level. Of the 178 sample firms, 58 firms (278 firm-years) were coded at the full or reduced billable rate of their respective auditors, 82 firms (441 firm-years) were coded at the estimated cost of their respective auditors, and 38 firms (260 firm-years) were coded for free by their firms' respective auditors. Many of the auditors agreed to charge a reduced price or forego payment for the coding if the timing of the coding was flexible because many of the managers of the coders suggested that assigning staff accountants the task of familiarizing themselves with the board minutes of clients was a helpful exercise for future audits. Other auditing firm managers cited professional reciprocity as the reason for reducing or waiving their billable rates for services rendered for this study.

\section{Appendix B: Content Analysis Protocols for Scientific Robustness}

The following protocols were taken to strengthen the reliability of board transcript coding:

\section{Sentence by sentence evaluation}

Board meeting agendas structure meeting communication into specific discussion topics. Utilizing this relatively high degree of communicative formality, coders were directed to first review the board meeting agenda for the respective meeting transcripts they were preparing to code. When the board meeting agenda specifically allocated discussion time for monitoring related topics, coders were instructed to highlight the beginning and end of the associated discussion in the board meeting transcripts. This procedure was done to help focus the coders' time and attention during the coding process. For the purposes of this study, ${ }^{10}$ and as an initial step to strengthen coding reliability, each coder was then instructed to read each sentence in the board minutes separately and ask him or herself the following questions:

- Is this sentence representative of the board monitoring the firm's management? (such as management's decisions or actions), or

- Is this sentence representative of the board attempting to control the management of the firm? (such as controlling management through alignment of their interest with those of shareholders - e.g., compensation).

After coding a firm's complete set of fiscal year meeting minutes by sentence, each coder categorized and summed the time, measured in minutes, allocated to monitoring. These codes were then sent to the researcher(s) for comparison between coders.

10. Due to the unique (and possibly one-time) access to these firms' board meeting transcripts and the start-up cost associated with securing and training coders, coders repeated the above steps for other discussion topics, such as competitive threats, corporate social responsibility, and financial and strategic evaluation. 


\section{Coding as a sequence}

As another procedure to strengthen reliability, the coding process was implemented as a set of sequential topic-specific phases (e.g., product and market opportunities; competitive threats; monitoring; corporate social responsibility; etc. . .) to reduce coding complexity. Coding instructions were designed to reduce the coding task to a clerical function (D'Aveni and Macmillan, 1990). These instructions, concept definitions, and accompanying 'indicator' word and phrase lists, including synonyms, were sent to coders only after he or she had completed the previous coding phase. To ensure accurate measurement of board meeting discussion time allocation on each topic, at least two coders were assigned to every set of firm-year transcripts and three coders were assigned to transcripts that were less structured (did not have time documentation throughout the dictation transcripts). Coders in the same accounting office were kept on separate phases to ensure independence in coding.

\section{Coding rules}

Following D'Aveni and MacMillan's (1990) coding design, this study's coders first followed the general coding rule of only coding explicit references to board monitoring (using indicator words and phrases). Next, coders were to look for 'references back' or sentences with an implicit (or supporting) reference to the indicator word or phrase. In contrast to D'Aveni and MacMillan (1990), which measured attention by sentence count, this study focuses on time allocation. Therefore, coders were instructed to demarcate sentences that supported the monitoring indicator words and phrases (or the sentences in which they were contained). When the indicator words or phrases were used in a manner that was not the focus of the discussion or not referring to the firm as the primary actor, coders were instructed not to categorize these words and phrases as monitoring. Coding discussion is a complex task. We began the pretest stage with over 10 nuanced rules for coding board discussions of monitoring. However, during the pretest coding, we found that many of the rules were unnecessary and resulted in coder confusion. However, when coders were instructed simply to focus on the indicator words and phrases and to determine if each sentence followed the instructional questions above, coders were able to execute their task efficiently and effectively. It is important to note, considering the relatively formal structure of most board meetings, board discussions provide a relatively simple topic coding task as compared to less formal discussions. As noted above in protocol one, the topics of board discussion are slated in the agenda prior to the meeting. Also contributing to the formality of board discussions are the 'rules of order' that are followed in most board meetings. These rules keep the discussion on-topic and on-agenda. The strictness of rule enforcement is often at a chairperson's discretion.

\section{Coder training}

Because it was agreed upon that each of the companies' respective auditing firm's employees were to serve as the coders of the transcripts, 271 coders at 56 various locations participated. To ensure reliability between coders and the validity of our procedure, two stages of pretests were conducted. The three firms, 21 firm-years, used for the pretests agreed to allow their board transcripts to be used as long as anonymity was assured. Each firm reviewed its respective transcripts after they were 'cleaned' of any identifying information and before they were sent to potential coders. For the first pretest, board transcripts for 14 firm-years were electronically sent to each potential coder with all identifying names disguised. Coders were also sent instructions and participated in Web conference meetings with this study's first author. The word and phrase list, the instructions, and the rules evolved as the pretests took place. Also, poor performing coders could be replaced. However, few coders needed replacement.

\section{Cross-coding transcripts}

For each company year, board meeting transcripts were assigned to at least two coders. The same coders were assigned all years of a company's transcripts. After all coders for a company had submitted their coding results to the researcher(s), one of the coders for the common set of transcripts was responsible for uploading the transcripts to a secure computer and automated text analysis software, N6, to search the 
electronic versions of the transcripts. ${ }^{11}$ This software was programmed with the monitoring indicator words or phrases. Then a copy of the transcripts was downloaded by the coder with the indicator words and phrases highlighted. Each coder then compared his or her coding results to make sure no indicator item had been overlooked. If an indicator was found to have been excluded by any of the coders, they reexamined the previously excluded item.

These indicator words and phrases were used to draw coders' attention to a certain section of the board transcripts. Coders then determined whether the word or phrase was used in a manner relevant to our study. The amount of time the boards spent discussing monitoring issues was subsequently used to measure the attention boards dedicated to monitoring activities. The time spent discussing monitoring as a proportion of total board meeting time was coded as the board's allocation of attention to monitoring.

Approximately two-thirds of the board transcripts document the board meeting time in great detail (usually dictated transcripts with time spent systematically recorded). For non-dictated transcripts, coders examined the amount of text regarding monitoring relative the entire text of the meeting and estimated what proportion of the board meeting was devoted to discussing monitoring. Inherently subjective, coder estimation presents a limitation on the value of these transcripts. To reduce this weakness, we put less detailed transcripts through the regular process of dual coding and, additionally, had a third coder review them when we encountered differences between coders of more than 10 percent; otherwise, the results were averaged.

\section{Negotiation of coders}

Coders were chosen by a contact partner in each auditing firm. For each sample company, a contact partner identified at least three accountants at different levels of career seniority to participate in the study. ${ }^{12}$ Most commonly, coder one was a new staff accountant (one to two years of experience), coder two was a senior accountant (three to five years of experience), and coder three was a manager (five plus years of experience). Coders one and two coded each set of transcripts. Coders were instructed to print out hard copies of the transcripts they coded and make notes on these files so they could recall and defend their coding results of this topic. Additionally, coders recorded the number of time each indicator word or phrase appeared in an annual set of transcripts, how many sentences focused on this topic, the total amount of time the board spent discussing this topic, and the percentage of the meeting devoted to monitoring. After each coder had coded his or her transcripts for a certain topic, he or she submitted the coded results to the researcher(s). Once both coders had submitted their coding results, the reliability between the coders was assessed by the researcher(s). If a certain threshold of agreement was achieved, 90 percent (determined by the researcher(s)), they were instructed to resolve any differences in coding. If differences were greater than 10 percent, the third coder was sent the instructions and indicator word and phrase list and instructed to code the specific firm-year transcripts with the conflict. After the third coder submitted his or her coding results, agreement between all three coders was assessed and coders were instructed to resolve differences in a post-negotiation meeting.

The carefully detailed coding instructions and protocols developed for this study were intended to minimize subjective judgments in the content recording process. While the coding results of any single coder are inherently subjectively derived within the confines of the coding rules and protocols, high intersubjective agreement between coders lends credence to the coding process and, therefore, the results.

11. In an effort to assure security of the documents, transcripts were promptly deleted after N6 was executed.

12. Some auditing firm offices had many sample firms to code and, therefore, assigned different teams of accountants to code different sample firms. 